\title{
Determinants of Work Motivation and Work Ability among Older Workers and Implications for the Desire for Continued Employment
}

\author{
Victoria Büsch, Dennis Dittrich, Uta Lieberum
}

\begin{abstract}
In times of demographic change, with the associated challenges for social security systems and the looming lack of skilled workers, extending working life becomes increasingly significant. According to the continuity theory (Atchley 1989) we can assume that individuals who are satisfied with their structures and performance will stay at work longer. We will therefore examine whether motivation and perceived work ability have an influence on the desire for continued employment. In addition, we will answer the question of whether factors that have a positive influence on motivation and work ability also have a direct influence on continued employment. Besides objective factors such as enterprise size and occupational status, we will examine subjective factors, such as assessment of recognition, the demands, and the meaningfulness of the work for their contributions to the explanation. The following analysis is based on a survey taken in May 2008 together with the Bundesinstitut für Bevölkerungsforschung (BiB). It enables us to identify the desire for continued employment in old age, the existing work motivation, and the state of health. The core results of the statistical analysis show that in men high motivation is linked to the desire for continued employment in retirement age. This does not apply to women; for them, work ability is the decisive criterion. In general, we observe that a positive assessment of the subjective influencing factors strengthen work motivation. In addition, with regard to objective factors it was ascertained that for men the working hour regime (full-time work) and occupation status (salaried "white-collar" employees) correlate positively with the desire for continued employment. In particular, meaningful work increases motivation among men and work ability increases motivation among women. It appears important that enterprises convince their employees of the meaningfulness of the work.
\end{abstract}

Keywords: Extended working life $\cdot$ Older workers $\cdot$ Employee motivation $\cdot$ Health

(C) Federal Institute for Population Research 2012 DOI: 10.4232/10.CPoS-2010-20en
URL: www.comparativepopulationstudies.de URN: urn:nbn:de:bib-cpos-2010-20en4 


\section{Introduction}

Demographic change has far-reaching consequences both for the labour market and for the pension insurance system in Germany. In the long term, a major decrease in the number of young gainfully employed persons in the labour market is foreseeable. In pension insurance, a shift in the number of contributors and pensioners in favour of pensioners is expected (Börsch-Supan 2011). The dependency ratio, which describes the ratio of older persons ("pensioners"), aged 65 and older to younger persons between the ages of 14 and 64 ("contributors"), is a relevant indicator for estimating intergenerational fiscal redistribution. It is developing unfavourably with regard to the funding of the system. While the ratio was 100:5 in the year 1890, shortly before introduction of pension insurance by Bismarck, it changed to $100: 32$ by the year 2005 and will presumably be 100:50 in 2030 .

In order to make pension insurance sustainably fundable, various reforms have raised the retirement age since the 1990s (Bäcker et al. 2009). The pension reform of 2007 will gradually raise the age limit from 65 to 67 years to retain deductionfree standard old age pensions from the year 2012. In 2029 the total increase will first come into effect for those born in the year 1964 (Mollenhauer 2006). It must, however, be taken into consideration that the factual retirement age averaging 63 years is lower than the deduction-free retirement age (Brussig/Wojtkowski 2006). In addition to the necessity of raising the standard retirement age the question is whether the gainfully employed persons are at all willing and capable of extending their working life. In the most recent past, there has been a rise in the time 55- to 64 -year-olds remain at work, so that in Germany the number of persons in this age group in employment rose from $39.9 \%$ in the year 2003 to $53.8 \%$ in the year 2008 (Eurostat 2010).

Therefore the central research issue is whether older workers are capable of fulfilling the demands of work in the long term. In practice, there continue to be (negative) stereotypes with regard to the work ability of older workers, which leads to preferential treatment of younger workers. This contributes to explaining increased physical deterioration in the industrial sector, which has led over time to the development of age images that can be described as obsolete for many of today's occupations (Laschart/Möller 2005). Meanwhile, gerontological and psychological studies show no evidence whatsoever of decreased work ability that can be ascribed to the increased age of workers. Various studies have shown that with regard to the work ability of older persons (a persons' performance as a function of their ability and motivation - cf. Klehe/Kleinmann 2007), the so-called deficiency model is not (or no longer) valid (Lehr 1990). A meta-analysis of more than 100 studies on occupational work ability also confirmed that there are no general differences between the work ability of older and younger workers in the same job (Warr 2001).

In spite of this, the mind-set still exists both among employers and employees that employees over 50 are no longer productive (Henkens 2005; Aschenbaum 2005). The International Labour Organization (ILO) has presented a report on discrimination that predicts an increase in discrimination (also of older workers) at the workplace. Büsch et al. (2009) even observe a distinctly lower recruitment probabil- 
ity of older applicants in spite of their productivity being assessed as equal to that of younger applicants (cf. ILO Global Report 2011; Commerzbank AG 2009). Hence, the central question for employees is the extent to which the workers desire to continue working after reaching retirement age and whether they feel capable of doing so. In 2008 infratest surveyed 1,500 workers between the ages of 55 and 65 years about their desires and expectations for possible continued employment (Büsch et al. 2010). The results of this survey are the basis of the data used in the analysis we present here.

This article consists of five sections. We begin by summarising the current research on continued employment of older people. Then, we discuss various factors influencing motivation and work ability. Based on this, we develop a model approach to be able to illustrate the correlation between the desire to work longer and work motivation as well as work ability and derive corresponding hypotheses. In the ensuing empirical section we examine the informational value of the model. The article ends with concluding remarks and a brief description of future prospects.

\section{Factors influencing the desire for continued employment}

The reasons for people wanting to continue in employment after reaching retirement age have not yet been clearly delineated, in particular in Germany. Instead, the debate on raising the retirement age in Germany has led to changes in the focus of research. While the focus was once on studies of early retirement decisions, in recent years there have been an increasing number of studies on the (desired) duration of employment (Kapteyn et al. 2007).

Terms for continued employment after reaching retirement age such as "bridge employment" and "silver work" have become established (Shultz 2003; Deller et al. 2007). Bridge employment is understood as the transitional phase between leaving one's previous full-time job and full retirement. This can be a phase, for example, in which a person works part time or undertakes a new type of work, such as selfemployment. So-called silver workers are active retirees aged between 60 and 85 years. Generally, a number of types can be differentiated in this context: partial retirement before reaching retirement age (active and passive), continued employment after reaching retirement age (in one's previous job or in a different area) or full retirement. Since the legal regulations promoting partial retirement were limited in time until 31 Dec. 2009 and were no longer extended, we can expect that in future there will be ever more persons who remain active even at an advanced age (Bundesagentur für Arbeit 2011).

Therefore, it appears advisable to look at reasons for the desire for continued employment in a differentiated way. In the literature role and continuity theories are often used to explain this situation (von Bonsdorff et al. 2009). According to the role theory there are symbols or roles that are perceived over the course of socialization and with which an individual identifies. These symbols are formed both by the individuals themselves and by their social environment (Mutran et al. 1997). Hence, the attitude towards retirement depends on the individual's social background and 
employee identity as well as on their expectations for their future retirement situation or role as a retiree. Depending upon one's assessment of the socioeconomic status yet achieved, people can regard the transition to retirement as liberation or as a loss (Carter/Cook 1995). Among those with higher vocational status in particular, the changed role is accompanied by an anticipated loss of power and prestige. Adjustment to the new life role is better achieved the more complete one's information of future life circumstances is. More details about this issue using the same data basis as this article can be found in Micheel et al. (2011 in CPoS 35, 4).

The continuity theory of ageing has very similar argumentation. One of its central assumptions is that individuals attempt to retain a balance between continuity and change in the structures of their lives. This is only conditionally possible in the ageing process, as there is no return to one's original condition once age-related events have occurred. The continuity theory also takes options to react to change into consideration. Individuals set goals with regard to their own future development. In doing so, they possess specific behavioural patterns that influence the fabric of their decisions. The behavioural patterns themselves are influenced by the individual's respective environment, so that the ageing process can be seen as culturally- or environmentally-related. Lieberman and Tobin (1983) emphasize that even when external circumstances change dramatically, an inner continuity remains, i.e. one's decision-making patterns remain relatively constant. The "higher the quality" of the vocational patterns established so far, the higher is the preference for maintaining these patterns (Quick/Moen 1998). This illustrates that to explain the decision-making processes in the transition to retirement we must not only consult outer circumstances, but that personal factors play just as central a role.

There are a large number of factors that influence retirement decisions. Based on Wang et al. (2008) and Wang/Schultz (2010), we differentiate between four groups of influencing factors (cf. Gobeski/Beehr 2009; Deller/Maxin 2010; van Dam et al. 2009):

- Personal factors

- Work and organisation-related factors

- Family-related factors

- Socio-economic factors

This article focuses on personal and organisation-related factors; therefore we will not elucidate the family-related and the socio-economic factors here.

\subsection{Personal factors}

Personal factors such as health and age play major roles in the decision to continue working. In a study of 346 workers over 50 years old in the Netherlands, these were asked about their motives for early or delayed retirement. The results made clear that a good state of health has a positive influence on extended working life (van Dam et al. 2009). Other studies also revealed that belonging to the working world plays a pivotal role in the age group of 50 to 59 -year olds. Positive feelings in con- 
junction with the workplace have great explanatory force for the reasons people consider continuing work after reaching retirement age (Phillipson/Smith 2005). These findings can be interpreted in line with the role theory, which emphasizes the importance of employee identification.

In the literature, gender is considered an important explanatory factor for differing attitudes, such as the attitude towards retirement (Koloski et al. 2001). One interesting difference between the sexes with regard to continued employment is the higher percentage of men who no longer wish to work upon reaching retirement age in spite of very good health (Beehr et al. 2000; Gärtner 2010). It can be assumed that women, in their more complex employment biographies, also exhibit longer breaks due to parental leaves and thus wish to remain in the vocational context with its opportunities for social interaction. In addition, for women factors such as social contacts with co-workers, independence, and flexibility play more significant roles in work, while for men the importance of the work is a more relevant factor (Shacklock et al. 2009).

Skills are another central factor in the decision to retire (Koloski et al. 2001). Employees with higher levels of education are more willing to continue working in the same field than to train for work in other fields (Wang et al. 2008). In a US survey from the year 2000 it was observed that persons with a higher level of education demonstrate a much higher probability of wanting to continue to work in "bridge employment" than persons with a lower level of education (von Bonsdorff et al. 2009).

\subsection{Work- and organisation-related factors}

Some work- and organisation-related factors that have proven relevant for the decision to continue working refer to enterprise size, position, and income.

A British study showed that in small enterprises with up to ten employees employment of older workers is far higher than in larger enterprises (Smeaton/McKay 2003). It can be assumed that this is because of the familial atmosphere and the identification related to this. Humphrey et al. (2003) showed that in particular persons with a lower job level work longer. However, the authors point out that this may well be due to a cohort effect that applies to this particular generation but does not always occur at this age.

According to Dorbritz and Micheel (2010) higher income does not lead to consideration of continued employment. This would concur with the argument that employees with lower income are more likely to feel the need to continue to work even beyond retirement age (Beehr 1986; Feldman 1994; Opaschowski 2008).

In addition to the objective factors cited, subjective aspects that are directly linked to the job or the workplace in particular appear to positively influence the decision to continue working (Beehr et al. 2000). These factors can include those that favour a high degree of identification with the enterprise. Results of empirical studies indicate the intrinsically motivating work factors that positively influence a decision for continued employment in the same environment (Gobeski/Beehr 2009). According to a Dutch study those surveyed are more likely to consider intrinsic fac- 
tors of work conditions such as meaningful tasks and ethical values important for a decision for continued employment after reaching retirement age (van Dam et al. 2009).

Furthermore, recognition and the support of co-workers and senior management play central roles in the desire for continued employment as motivating factors for vocational work in old age (van Dam et al. 2009). Also, needs-tailored and demands-tailored configuration of the work appears to be an important influencing factor for the decision for continued employment, as a qualitative study in Germany shows (Deller/Maxin 2010).

\section{Factors influencing work motivation and work ability among older employees}

We will first describe the motivation and work ability of older workers regardless of their desire for continued employment and discuss possible influencing factors. It is assumed that although older employees demonstrate a high degree of work motivation and are highly motivated, nonetheless different factors play a role among older and younger employees. We will therefore first present factors that correlate positively with a higher motivation in particular among older employees. Generally motives develop or change over the course of time and are stimulated by experiences. Against the study background we will focus on the motivational aspects that are particularly relevant for older employees.

\subsection{Objective factors influencing work motivation}

The results of various studies show no noteworthy difference between different age groups with regard to motivation. But this also means that older workers are not less motivated than younger workers. Basically, empirical studies reveal that the work motivation of older employees is high (Rab/ 2010; Kooji et al. 2010). Also, no studies have been able to provide evidence confirming the generally negative age stereotypes (Stamov Rossnage/ 2009; Grube/Hertel 2008). However, there are indications from studies that the factors behind motivation differ between age groups (Rhodes 1983; Lord 2002; Kanfer/Ackermann 2004; Lord/Farrington 2006; Rab/ 2010; Stamov Rossnagel 2009; Kooij et al. 2010). We will briefly discuss these factors in the following.

With regard to the differing motives among age groups we can say that the importance of career and further training motives lessen somewhat with age. In newer studies, extrinsic motives such as the achievement of a certain social status and the results effect of work are more likely to be perceived as less important with advanced age. By contrast, intrinsic motives such as independence, collaboration with others, the perception of own performance and independently completing the tasks increase with age (Kooji et al. 2010).

Gender is another objective personal criterion. In various empirical studies on employee motivation hardly any differences were ascertained between the sexes 
(Hauser et al. 2007). Studies suggest that although the percentage of motivated men and women is practically the same, the factors that influence the motivation can be different for the genders. This is illustrated for instance in higher significance of soft enterprise factors (such as company philosophy) among female applicants and employees (berufsstart.de 2006).

Skills are a third objective influencing factor. The impact of differences in skills on motivation may be explained in part by content theories, which often differentiate between deficiency and growth motivators. Unlike growth motivators deficiency motivators are characterised by the fact that their fulfilment avoids dissatisfaction, but does not induce any additional motivation (Maslow 2010; Herzberg et al. 2010). The needs of people with a higher level of education are usually already at a higher level of satisfaction, since needs such as a suitable salary, social interaction, and to some extent also recognition and skills enhancement as well as career are already met.

We can state that both gender and skills of employees may have an influence on the types of motivating factors with advanced age, but that general motivation is not different.

The objective organisation-related factors include enterprise size, position within an enterprise and income.

We can assume that social interaction plays a greater role in smaller enterprises so that appreciation and recognition are more likely to be given. In a direct comparison of job satisfaction and employee dedication according to the different size ranges Hauser et al. (2007) identified no significant differences. Only a weak trend was observed: satisfaction and the active components of dedication were slightly more positive in small enterprises than in larger enterprises. According to this in small enterprises the company culture is experienced somewhat more positively than in medium-sized companies and in these, in turn, somewhat more positively than in large enterprises. In most studies, consideration of the position in the enterprise refers to a differentiation between persons with and without management responsibility. According to empirical findings senior managers are, however, not generally more highly motivated than employees without management functions (Sebald/Kramarsch 2007). But, for them other motivating factors apply (freedom to make decisions, innovations and learning and development opportunities) than for non-senior managers (reputation of the enterprise, advancement and career opportunities, interest of the enterprise in the employees) (Küppers/Wunderer 2001, 2003).

Lastly, financial aspects are relevant to the explanation of a desire for continued employment, because they can have existential significance. In extreme cases, employees could be forced to continue working for financial reasons. Then, their work motivation may have no influence on their decision. This view is largely supported by a qualitative study of 29 engineers over the age of 55 years concerning factors at the workplace and their impact on productivity and bonds to the enterprise. They were basically asked whether or not their income was sufficient to enter retirement. The responses showed that employees with sufficient income tend to consider social needs as important. The workers who assessed their income as insufficient 
were more likely to assess enterprise conditions such as security, pay, and working conditions as important. These factors display a rather low effect on motivation or work attitudes and satisfaction. By contrast, the so-called motivators, such as responsibility and work, are said to have a very high effect (Lord 2002).

Salary aspects tend to play a role in the middle employment ages, whereby they also depend on family situations. Here, too, we can assume that objectives change over the course of a lifetime (Grube/Herte/ 2008).

Although there were also no general differences in the motivation of age groups in the objective organisation-related factors, there were in differentiating factors that bring about motivation. This may indicate that subjectively perceived factors are more likely to cause an increase in motivation. These will be discussed in the next chapter and examined in the empirical section following it.

\subsection{Subjective influencing factors work motivation}

Besides actual circumstances, subjective perceptions are also important with regard to continued employment in retirement age. The following five aspects are taken into consideration here: demands of the work, management and/or recognition, assessment of the meaningfulness of the work, and solidarity with the enterprise. The first finding concerning this spectrum of factors is that work motivation becomes more task-specific for older employees. Some tasks lower motivation, while other tasks keep it at the same level or even raise motivation. This can, for example, lead to greater motivation among older employees if tasks are dealt with in a team, while lower motivation can be assumed for tasks that involve new content. All in all, younger employees are more likely to focus on longer-term goals, while for older employees direct motivators have the greatest influence (Stamov Rossnage/ 2009). Results from various studies also show that the work itself or the assessment of the meaningfulness of one's own work is decisive for older employees. This is enhanced by the opportunity to work in teams: positive social contacts and passing on knowledge are important attributes for older employees in enterprises (Stamov Rossnage/ 2009). The goals with future-oriented aspects such as learning, feedback, and work variety decrease, while enjoyment of the work, the working climate, and independence are aspects that gain importance with age (Grube/Herte/ 2008).

With age, the motivation for social tasks grows (e.g. passing on knowledge), while the motivation for informative tasks (e.g. contributing expertise) remains about the same and the motivation to learn new things is more likely to decrease. Here, as well, a positive connection was ascertained between motivation and job satisfaction. Older workers develop a growing need to optimise their mental wellbeing (Stamov Rossnage/ 2009).

All in all, recognition and appreciation are central motivating factors for working at an older age (Del/er/Maxin 2010). Therefore the factors that increase in importance with age are those such as work climate, management, community and independence or material and immaterial recognition, enjoyment of work, demands, assessment of self-determination and the perception of meaningful work. 
These findings suggest that management should adapt to changed needs. This means that a positive attitude of senior managers towards older employees and the appreciation of their vocational experience and expertise are decisive for motivated work.

Solidarity with the enterprise also differs with age. Younger employees are more likely to remain with a company for material reasons, while older employees feel more loyalty. Reasons for staying with an enterprise also showed that younger employees in particular consider the financial necessity and more material security aspects important. By contrast, older employees tend to enjoy the work more and are proud of their own work. Identification with the work is therefore particularly important (Lord/Farrington 2006). A survey by Zacher et al. (2009) reached similar results. Older employees find goals in the area of company commitment more significant (e.g. improving operational processes and structures). For younger employees, goals in the areas of skills enhancement and higher pay or career opportunities are more important.

\subsection{Factors influencing work ability}

Vocational work ability is a matter both of mental capacity and physical fitness. We differentiate between crystallised (experience-related) and fluid (mechanical) intelligence (Kruse 2000) when speaking of mental capacity. The former refers to factors such as routinely carrying out intellectual and physical tasks. Since older employees have more experience with their work, it is not surprising that positive correlations are ascertained between age and performance in this context (Warr 2001). A decrease in fluid intelligence is observed as adults age, which although accompanied by a reduced speed in processing information can be compensated by routine or knowledge from experience (Kruse 2000).

In this study work ability consists mainly of characteristics that measure the state of health. Health is an obligatory condition for the ability to continue employment. Subjects are still asked to assess their own work ability with regard to the work demands based on the Work Ability Index by IImarinen. Various studies demonstrate that the differences in performance within an age group are by far greater than those between different age groups (Kruse 2000; IImarinen 2005). It must also be taken into consideration that there are no monocausal links between age and work ability. Warr (1994) pointed out, for instance, that the majority of psychological studies explore the question of how age affects the ability to work and not how work affects the ability in old age (Warr 1994).

This analysis will furthermore examine the factors of gender, skills, position, and income with regard to their significance for work ability. A longitudinal study in Finland has been unable to find any differences in men and women with regard to their ability to work (/Imarinen et al. 1997). As for skills, there are indications that a higher skill level goes hand in hand with higher work ability. Also, it becomes apparent that an individual's position in the enterprise has a positive influence on work ability (Aittomäki et al. 2003). Due to the prevailing seniority-based pay in Germany we are unable to measure the influence of income on productivity (Skirbekk 2003). 
In addition to the personal and organisation-related objective factors cited, we will also examine the influence of subjective factors. We assume that the perception of surrounding conditions is relevant for a person's work ability. Biomedicine shows that personal performance rates result from various environmental conditions. The stimulating environment consists both of one's personal environment and the working world (Rump/Eilers 2009). Tuomi et al. (2001) show that work demands and work environment play the greatest role in explaining the extent of work ability. For instance, the simple colour coding of work materials can contribute to increasing productivity. On the other hand, monotonous work can reduce work ability (Warr 2001). A study conducted in Denmark also illustrates that work-related factors have the greatest explanatory force for work ability (Alavinia et al. 2007). Moreover, the model devised for the ability to work contains the aspect of management as an explanatory variable for the ability to work (I/marinen/Tuomi 2004).

\section{$4 \quad$ Model explaining the desire for continued employment}

In this section, we will transfer the personal and organisation-related aspects to a model serving as the basis for testing the hypotheses yet to be developed. Based on the continuity theory, we will assume that if a high degree of motivation and high self-assessed work ability have been attained in one's past working life this has a positive influence on the desire for continued employment.

In addition, we will differentiate between objective and subjective factors that can influence motivation or work ability based on the existing empirical findings and taking the criteria described by Wang and Shultz (2010) into account. The objective factors are additionally broken down into personal and organisation-related factors (Fig. 1).

With regard to objective influencing factors there is, for one, the reference to the individual, or properties such as age, gender, and skills, and then there is the reference to the enterprise, including factors such as enterprise size, position, and income. The objective factors are therefore quantifiable quantities that are usually clearly definable regardless of subjective assessments. By contrast, the subjective assessments of the workers with regard to the enterprise are always dependent on the individual. Therefore, the subjective influencing factors are always based on assessments that refer to the enterprise in particular, but the characteristics are not independent of the individual, so that in Table 1 we did not strictly differentiate between personal and organisation-related factors The factors taken into consideration here are the demands of the job or work, recognition or management, the perceived value (meaningfulness) of the work, and solidarity (bonds) with the enterprise (Tab. 1).

The influencing factors will be examined for their relevance to motivation and the ability to work and, as a consequence, to the desire for continued employment. Work ability refers primarily to health aspects, but also indicates self-assessed work ability with regard to work content. The construct contains 15 items following the Work Ability Index (cf. section 5.1: Construction of the latent variables). 
Fig. 1: Desire for continued employment taking motivation and work ability in account

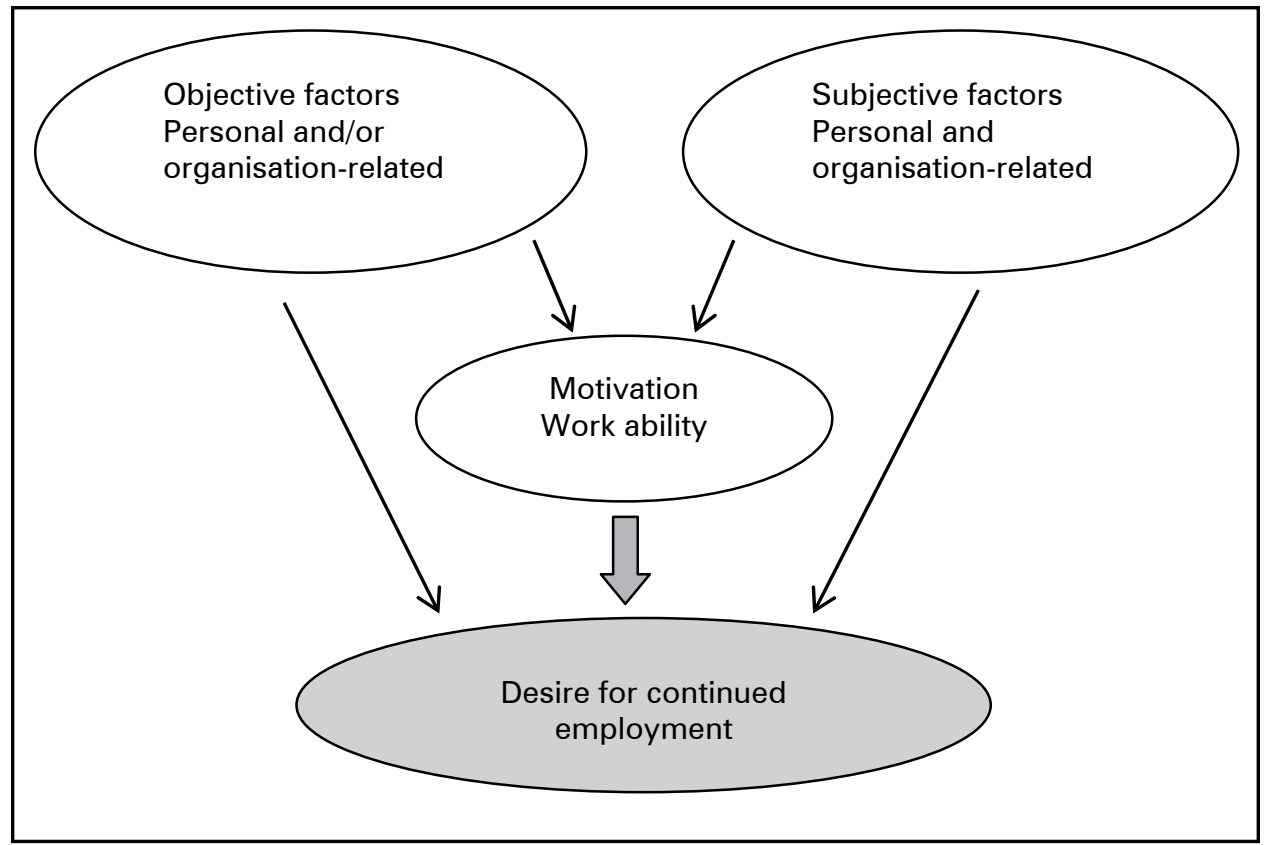

Source: own design

Tab. 1: Classification of influencing factors

\begin{tabular}{lll}
\hline & Personal factors & Organisation-related factors \\
\hline Objective & Age & Enterprise size \\
& Gender & Position \\
& Skills & Income \\
Subjective & & Work demands \\
& & Work recognition \\
& Management \\
& & Meaningful work \\
& Organisational bonds \\
\hline
\end{tabular}

Source: own design 
To test the model, we have derived five hypotheses from the descriptions of the influencing factors on motivation and work ability of older employees:

Hypothesis 1: High motivation has a positive influence on the desire for continued employment upon reaching retirement age.

Hypothesis 2: High work ability has a positive influence on the desire for continued employment upon reaching retirement age.

Hypothesis 3: The objective and subjective influencing factors have a direct influence on the desire for continued employment. The more positively the factors are perceived, the greater is the desire for continued employment.

Hypothesis 4: A positive assessment of the subjective factors correlates positively with the motivation of older workers.

Hypothesis 5: A positive assessment of the subjective factors correlates positively with the assessment of personal work ability.

\section{Survey and evaluation}

In order to test the five hypotheses, we used the data from a survey conducted in a cooperation between the Bundesinstitut für Bevölkerungsforschung and the SRH Hochschule Berlin. This survey explicitly asks subjects about their willingness to continue working in old age (Büsch et al. 2010). The subjects were asked whether they wish to remain gainfully employed after they reach retirement age. In addition, various socioeconomic data were surveyed such as gender, income, occupational status, etc. The sample encompasses 1,500 individuals and is representative of employees in the reviewed age group of 55-64 years. In this sample, which is described in Table 2, only gainfully employed persons are represented (blue- and white-collar workers subject to social insurance contributions, civil servants, marginal part-time employees). We did not include retirees, pensioners, self-employed persons, unemployed persons, short-time workers, or employees on leave of absence. The question of a desire for continued employment did not seem wise against the background of unemployment. 
Tab. 2: Description of the sample

\begin{tabular}{|c|c|}
\hline Variable & Relative frequency in \% \\
\hline \multicolumn{2}{|l|}{ Gender } \\
\hline Male & 55.5 \\
\hline Female & 44.5 \\
\hline \multicolumn{2}{|l|}{ Age } \\
\hline $55-59$ & 73.3 \\
\hline $60-64$ & 26.7 \\
\hline \multicolumn{2}{|l|}{ Vocational training } \\
\hline No vocational training completed & 4.09 \\
\hline Apprenticeship or comparable training & 50.24 \\
\hline Master, technician or comparable technical school diploma & 17.05 \\
\hline University of applied science or university diploma & 27.63 \\
\hline \multicolumn{2}{|l|}{ Extent of gainful employment } \\
\hline Full time & 76.79 \\
\hline Part time (15-35 hours per week) & 17.86 \\
\hline Marginal (less than 15 hours per week) & 5.35 \\
\hline \multicolumn{2}{|l|}{ Vocational position } \\
\hline Manual workers & 32.04 \\
\hline Non-manual workers & 57.60 \\
\hline Civil servants & 10.36 \\
\hline \multicolumn{2}{|l|}{ Vocational status } \\
\hline Under-skilled & 20.56 \\
\hline Skilled & 48.24 \\
\hline Highly skilled & 31.20 \\
\hline \multicolumn{2}{|l|}{ Enterprise size } \\
\hline Less than 10 employees & 13.70 \\
\hline $10-49$ & 24.67 \\
\hline $50-249$ & 27.55 \\
\hline $250-499$ & 33.41 \\
\hline \multicolumn{2}{|l|}{ Monthly net household income } \\
\hline Less than 1,000 euros & 4.55 \\
\hline $1,000-1,999$ & 32.34 \\
\hline $2,000-2,999$ & 29.33 \\
\hline $3,000-3,999$ & 14.76 \\
\hline 4,000 euros and more & 13.48 \\
\hline Not specified & 5.54 \\
\hline
\end{tabular}

Source: Data set "Weiterbeschäftigung im Rentenalter", own calculations 


\subsection{Construction of the latent variables}

In this sub-section, we will document the construction of the latent variables used in the analysis and their internal consistency (Cronbach 1951). The latent variable is constructed by adding up the respective single items following possible needed rescaling to a common range of values. Then all latent variables are standardized for the analysis, i.e. they then have a mean value of 0 and a standard deviation of 0.5. This allows for direct comparison of the corresponding regression coefficients, in particular also with dichotomous indicator variables. The correlations of latent variables to one another are portrayed in Table 3.

Tab. 3: The correlations of latent variables to one another

\begin{tabular}{lcrrrrr}
\hline & \multicolumn{1}{c}{ 1. } & \multicolumn{1}{c}{. } & \multicolumn{1}{c}{ 4. } & \multicolumn{1}{c}{5.} & \multicolumn{1}{c}{6.} \\
\hline 1. Work demands & 1,00 & 0,20 & $-0,08$ & 0,10 & $-0,01$ & $-0,20$ \\
2. Work recognition & 0,20 & 1,00 & $-0,40$ & $-0,41$ & 0,17 & $-0,30$ \\
3. Management & $-0,08$ & $-0,40$ & 1,00 & 0,21 & $-0,00$ & 0,09 \\
4. Meaningful work & 0,10 & $-0,41$ & 0,21 & 1,00 & $-0,04$ & $-0,28$ \\
5. Organisational bonds & $-0,01$ & 0,17 & $-0,00$ & $-0,04$ & 1,00 & $-0,06$ \\
6. Work Ability & $-0,20$ & $-0,30$ & 0,09 & 0,28 & $-0,06$ & 1,00 \\
\hline
\end{tabular}

Source: Data set “Weiterbeschäftigung im Rentenalter", own calculations

\section{Work demands}

Based on the effort construct of Siegrist et al. (2004) the latent variable of work demands is constructed of seven items: "My work requires great concentration," "My work demands that I make rapid decisions," "My work demands high work speed," "My work is strenuous," "My work is involved with a great deal of responsibility," "My work is physically strenuous," "After work I feel exhausted." The items are each measured on a five-point scale. The internal consistency of the latent variable work demands under Cronbach's alpha is 0.71 .

\section{Work recognition}

Based on the reward construct of Siegrist et al. (2004) the latent variable of work recognition is constructed of seven items: "My co-workers criticise me for every little thing," "The work climate is not as I'd imagine it should be," "Complaints and suggestions by my co-workers and myself usually receive no attention," "My relationship with my supervisor is cooperative," "I receive too little pay for my work," "If I could, I would like to change jobs," "My workplace is safe." The items are each measured on a five-point scale. The internal consistency of the construct is 0.66 . 


\section{Management}

The latent variable of management/leadership consists of three items: "My supervisor often makes the wrong decisions," "My supervisor informs me in detail of important matters," "My supervisor gives me clear and comprehensible instructions." The items are each measured on a five-point scale. The internal consistency of the construct is 0.67 .

\section{Meaningful work}

The latent variable of meaningfulness and identification with the work is constructed of five items: "My work is meaningful," "I identify with the objectives of my enterprise," "I make a major contribution to attaining the objectives of the enterprise," "I am very satisfied with my work," "After completing my work, I often have the feeling that I have made a contribution." The items are each measured on a five-point scale. The internal consistency of the construct is 0.63 .

\section{Organisational bonds}

The latent variable of organisational bonds consists of three items, which, due to their different scales are brought to a common scale before addition: "Duration of employment with the enterprise," "Number of previous employers," "Number of phases of unemployment." The internal consistency of the construct is 0.66 .

\section{Work ability}

The ability to work based on health according to the Work Ability Index of Tuomi et al. (2001) consist of 15 items: "How high do you assess your present work ability with regard to the content of your work?", "How high do you think your work ability will be with regard to the content of your work five years from now?", "Present general state of health" and twelve specific physical and psychological clinical pictures. The internal consistency of the construct is 0.85 .

\section{Work motivation}

The item motivation asks the extent to which the statement "My work motivation is very high" applies. Both the dichotomisation of the variables of work motivation in the categories "Disagree" and "Agree" including "Neither / Nor" and the use of the variables as a cardinal scale measurement of work motivation lead to the same result with regard to the desire for continued employment.

\subsection{Results of the analysis}

One of the first results of the survey is that nearly half of those surveyed could envision continuing to work. Nevertheless, only $5.8 \%$ of those surveyed actually 
cited a desire to postpone retirement after reaching their individually anticipated retirement ages, while $63.1 \%$ desire an earlier retirement than they presently anticipate. Correspondingly only $17.0 \%$ of those surveyed assess the gradual rise in the retirement age as "rather good" or "very good" but $69.0 \%$ as "rather bad" or "very bad."

In the following we will examine the dependency of the personal desire for continued employment on the above cited objective and subjective factors. Since the desire for continued employment after reaching retirement in the survey was measured on an ordinal scale of four categories and there is no approximated normal distribution, ordered logit models are used to analyse the desire for continued employment (Agresti 2010).

We first examined the direct effect of work motivation and good health on the desire for continued employment without taking other available variables (see Tab. 2 and Section 5.1) into consideration. The evaluation reveals a significantly positive effect of work motivation on the desire for continued employment, while the measured positive effect of health on the desire for continued employment is not statistically significant (see Tab. 4). Hence the data do not contradict the first hypothesis, but the second hypothesis is not supported by the data according to this analysis. Additionally, a likelihood ratio test shows that there is no statistically significant interaction effect between work motivation and work ability $\left(X^{2}=1.39\right.$; $\mathrm{DF}=1 ; \mathrm{p}=0.24)$.

Before examining the effect of work motivation and work ability on the desire for continued employment taking the other available variables into account, we need to examine whether and to what extent these variables explain the variance of work motivation and work ability.

Since work motivation is also only available on an ordinal scale and there is also no approximated normal distribution, an analysis of deviance based on an ordered logit model was used. Work ability, by contrast, demonstrates approximated normal distribution so that we can use an analysis of variance as the basis here.

Tab. 4: Logit models - analysis of the importance of motivation and health for the desire for continued employment

\begin{tabular}{lccc}
\hline & Model 1 & Model 2 & Model 3 \\
\hline Motivation & $0.22^{*}$ & & $0.20^{*}$ \\
Health & $(0.10)$ & & $(0.10)$ \\
& & 0.13 & 0.08 \\
Control variables & No & $(0.10)$ & $(0.10)$ \\
Gamma & 0.10 & No & No \\
\hline
\end{tabular}

${ }^{*}=$ significant at the level of $.05,{ }^{*}=$ significant at the level of .01 ,

The figures in the brackets are standard errors. Gamma measures the fit of the ordered logit model similarly to an R2 (cf. Goodman/Kruskal 1954).

Source: Data set "Weiterbeschäftigung im Rentenalter", own calculations 
Tab. 5: Analysis of deviance of work motivation

\begin{tabular}{lrllllllll}
\hline Factors & \multicolumn{3}{c}{ Total data set } & \multicolumn{3}{c}{ Men } & \multicolumn{3}{c}{ Women } \\
& LR $X^{2}$ & DF $P\left(>X^{2}\right)$ & LR $X^{2}$ & DF $P\left(>X^{2}\right)$ & LR $X^{2}$ & DF & $P\left(>X^{2}\right)$ \\
\hline Gender & 2.2 & 1 & 0.14 & & & & & & \\
Age & 11.9 & 9 & 0.22 & 20.4 & 9 & $0.05^{*}$ & 10.2 & 9 & 0.33 \\
Educational level & 5.1 & 5 & 0.41 & 7.3 & 5 & 0.20 & 2.3 & 5 & 0.81 \\
Working hours & 0.5 & 2 & 0.79 & 0.4 & 2 & 0.83 & 0.3 & 2 & 0.87 \\
Vocational position & 1.0 & 2 & 0.60 & 1.6 & 2 & 0.45 & 0.3 & 2 & 0.88 \\
Income & 16.3 & 10 & 0.09 & 16.7 & 10 & 0.08 & 22.2 & 10 & 0.01 \\
Enterprise size & 3.8 & 7 & 0.80 & 5.6 & 7 & 0.58 & 3.5 & 7 & 0.84 \\
Status & 3.4 & 2 & 0.18 & 6.2 & 2 & $0.05^{*}$ & 2.3 & 2 & 0.32 \\
Meaningfulness & 309.0 & 1 & $<0.01^{* *}$ & 202.3 & 1 & $<0.01^{*}$ & 100.0 & 1 & $<0.01$ \\
Demands & 3.8 & 1 & 0.05 & 2.1 & 1 & 0.14 & 2.3 & 1 & 0.13 \\
Recognition & 6.2 & 1 & $0.01^{*}$ & 2.2 & 1 & 0.14 & 4.7 & 1 & $0.03^{*}$ \\
Organisational bonds & 3.4 & 1 & 0.06 & 0.6 & 1 & 0.43 & 2.8 & 1 & 0.09 \\
Management & 5.5 & 1 & $0.02^{*}$ & 4.1 & 1 & $0.04^{*}$ & 2.2 & 1 & 0.14 \\
\hline
\end{tabular}

The column LR $\mathrm{X}^{2}$ shows the $\mathrm{chi}^{2}$ statistic of the likelihood ratio test, column DF the corresponding degrees of freedom, and column $\mathrm{P}\left(>\mathrm{X}^{2}\right)$ the $\mathrm{P}$ value of the chi ${ }^{2}$ statistic of the cited degrees of freedom.

${ }^{*}=$ significant at the level of $.05,{ }^{*}=$ significant at the level of .01 ,

Source: Data set "Weiterbeschäftigung im Rentenalter", own calculations

A likelihood ratio test indicates that there are significant differences between male and female survey participants with regard to the tested subjective and objective factors explaining the work motivation $\left(X^{2}=59.4 ; D F=40 ; p=0.02\right.$; see Tab. 5). All in all, some of the deviance in work motivation can be explained by the perceived meaningfulness of the work, recognition on the job, and management leadership - each with a positive correlation. Separate tests of male and female participants reveals that the statistical significance of recognition on the job is only given in the sub-sample of female participants, whereas the statistical significance of management/leadership is only given in the explanation of work motivation in the male sub-sample. In addition, there are statistically significant age differences in work motivation and an influence by vocational status in the male sub-sample (motivation increases with age, to then drop again in the oldest age group; men at the middle hierarchical level have less motivation) and a statistically significant effect of household income in the female sub-sample (high and low income correlate with higher work motivation). Hypothesis 4, which postulates a positive correlation of the subjective factors with the motivation of older workers, can only be verified for the perceived meaningfulness of the work. This applies for the subjective factors of work recognition and management/leadership in each case only in the sub-samples of the women or men participating in the survey. 
Tab. 6: Analysis of covariance of health

\begin{tabular}{lrrrc}
\hline Response & Sum Sq & DF & F value & $\operatorname{Pr}(>\mathrm{F})$ \\
\hline Gender & 2.14 & 1 & 10.83 & $<0.01^{* *}$ \\
Age & 2.84 & 9 & 1.60 & 0.11 \\
Educational level & 2.09 & 5 & 2.11 & 0.06 \\
Working hours & 1.12 & 2 & 2.84 & 0.06 \\
Vocational position & 0.54 & 2 & 1.36 & 0.26 \\
Income & 4.34 & 10 & 2.20 & $0.02^{*}$ \\
Enterprise size & 2.80 & 7 & 2.03 & $0.05^{*}$ \\
Status & 0.88 & 2 & 2.23 & 0.11 \\
Meaningfulness & 14.60 & 1 & 73.93 & $<0.01^{* *}$ \\
Demands & 11.00 & 1 & 55.73 & $<0.01^{* *}$ \\
Recognition & 4.14 & 1 & 20.97 & $<0.01^{*}$ \\
Organisational bonds & 0.14 & 1 & 0.72 & 0.39 \\
Management & 0.01 & 1 & 0.07 & 0.80 \\
Residuals & 286.40 & 1450 & & \\
\hline
\end{tabular}

${ }^{*}=$ significant at the level of $.05,{ }^{*}=$ significant at the level of .01 ,

Source: Data set "Weiterbeschäftigung im Rentenalter", own calculations

A linear model is estimated for the state of health since the characteristic studied exhibits sufficient normal distribution. The results of the analysis of covariance are shown in Table 6. An F-test reveals no significant gender differences explaining health using the subjective and objective factors ( $F=0.92 ; D F=40 ; p=0.61)$.

The variance of work ability can be explained with statistical significance by the perceived meaningfulness of the work (the linear regressions used as the basis for the analysis of covariance - not additionally reported here-ceteris paribus shows a negative correlation of the meaningfulness of the work and work ability), the job demands and recognition (each a positive correlation), gender (women have less work ability), income (non-linear relation), and enterprise size (negative correlation).

The data do not falsify hypothesis 5; work ability correlates only with some of the subjective factors such as demands and recognition.

Lastly, we can examine the effect of work motivation and work ability on the desire for continued employment taking the other available variables into account. A likelihood ratio test shows that there are significant gender differences for the explanation of the desire for continued employment through the studied subjective and objective factors $\left(X^{2}=74.38 ; D F=42 ; p<0.01\right)$. Table 7 reports the regression result of the ordered logit model taking the other objective and subjective control variables into account as in Table 4, however additionally divided up by male and female survey participants. After accounting for the control variables the effect sizes of both motivation and work ability increase; both variables are now statistically significant. The separate consideration of female and male participants, however, 
reveals that motivation makes a significant contribution to explaining the desire for continued employment only for male and work ability only for female participants. Table 8 shows the results of the corresponding analysis of deviance.

Tab. 7: Desire for continued employment and work motivation and health taking other objective and subjective factors into account as control variables

\begin{tabular}{lccc}
\hline & Total data set & Men & Women \\
\hline Motivation & $0.28^{*}$ & $0.58^{* *}$ & -0.09 \\
Health & $(0.12)$ & $(0.16)$ & $(0.19)$ \\
& $0.24^{*}$ & 0.16 & $0.34^{*}$ \\
Control variables & $(0.11)$ & $(0.16)$ & $(0.17)$ \\
Gamma & Yes & Yes & Yes \\
\hline
\end{tabular}

Source: Data set "Weiterbeschäftigung im Rentenalter", own calculations

Tab. 8: Analysis of deviance of the desire for continued employment

\begin{tabular}{|c|c|c|c|c|c|c|c|c|c|}
\hline \multirow[t]{2}{*}{ Factors } & \multicolumn{3}{|c|}{ Total data set } & \multicolumn{3}{|c|}{ Men } & \multicolumn{3}{|c|}{ Women } \\
\hline & $\operatorname{LR} X^{2}$ & DF & $\operatorname{Pr}\left(>X^{2}\right)$ & $\operatorname{LR} X^{2}$ & DF & $\operatorname{Pr}\left(>X^{2}\right)$ & $\operatorname{LR} X^{2}$ & DF & $\operatorname{Pr}\left(>X^{2}\right)$ \\
\hline Motivation & 5.6 & 1 & $0.02^{*}$ & 13.5 & 1 & $<0.01 * *$ & 0.2 & 1 & 0.63 \\
\hline Work ability & 4.5 & 1 & $0.03^{*}$ & 1.1 & 1 & 0.30 & 4.3 & 1 & $0.04^{*}$ \\
\hline Gender & 6.9 & 1 & $0.01 * *$ & & & & & & \\
\hline Age & 19.0 & 9 & $0.03^{*}$ & 12.1 & 9 & 0.21 & 10.4 & 9 & 0.32 \\
\hline Educational level & 8.2 & 5 & 0.15 & 4.6 & 5 & 0.47 & 4.8 & 5 & 0.44 \\
\hline Working hours & 5.4 & 2 & 0.07 & 9.4 & 2 & $0.01 * *$ & 1.6 & 2 & 0.46 \\
\hline Vocational position & 13.4 & 2 & $<0.01^{* *}$ & 22.4 & 2 & $<0.01 * *$ & 0.8 & 2 & 0.67 \\
\hline Income & 40.2 & 10 & $<0.01 * *$ & 29.6 & 10 & $<0.01^{* *}$ & 16.2 & 10 & 0.09 \\
\hline Enterprise size & 21.0 & 6 & $<0.01 * *$ & 18.4 & 6 & $0.01 * *$ & 12.1 & 6 & 0.06 \\
\hline Status & 1.9 & 2 & 0.39 & 4.3 & 2 & 0.12 & 16.5 & 2 & $<0.01^{* *}$ \\
\hline Meaningfulness & 0.1 & 1 & 0.83 & 0.1 & 1 & 0.75 & $<0.1$ & 1 & 0.89 \\
\hline Demands & 2.0 & 1 & 0.16 & 0.2 & 1 & 0.66 & 1.5 & 1 & 0.21 \\
\hline Recognition & 7.3 & 1 & $0.01 * *$ & 12.3 & 1 & $<0.01^{* *}$ & 0.2 & 1 & 0.68 \\
\hline $\begin{array}{l}\text { Organizational } \\
\text { bonds }\end{array}$ & 15.0 & 1 & $<0.01 * *$ & 4.7 & 1 & $0.03^{*}$ & 12.4 & 1 & $<0.01^{* *}$ \\
\hline Management & 0.2 & 1 & 0.66 & 0.9 & 1 & 0.36 & 0.1 & 1 & 0.78 \\
\hline
\end{tabular}

${ }^{*}=$ significant at the level of $.05,{ }^{* *}=$ significant at the level of .01 ,

Source: Data set "Weiterbeschäftigung im Rentenalter", own calculations 
The data do not falsify hypothesis 3. The desire for continued employment correlates both directly with some of the objective and some of the subjective factors. It is striking that there are hardly any overlaps among the genders with regard to the objective and subjective factors that can explain the deviance in the desire for continued employment with statistical significance.

\section{Conclusions and prospects}

This study analysed which factors positively influence the willingness for continued employment after reaching the retirement age. First of all it shows that almost half of those surveyed can envision continuing work after reaching retirement age. However, men and women are influenced by different factors with regard to their desire for continued employment.

In hypotheses 1 and 2 derived from the continuity theory (Atchley 1989) we assume that a positive assessment of motivation and work ability correlate with a greater desire for continued employment upon reaching retirement age. With regard to these hypotheses we can state that after taking the available control variables into account these hypotheses cannot be rejected. Nonetheless the data in the sub-sample of participating women do not support hypothesis 1 . This means that high motivation only correlates positively with the desire for continued employment among men. By contrast, hypothesis 2, which assumes a positive influence from work ability, is only supported in the sub-sample of women. We illustrated that the desire for continued employment is significantly influenced in men by motivation and in women by work ability. It is also apparent on the basis of hypothesis 4 that a positive assessment of the subjective influencing factors correlates positively with the degree of motivation. This applies, to varying degrees, with recognition and management as well as work demands. Also, the assessment of work ability, in agreement with hypothesis 5, correlates with some of the subjective factors (demands and recognition) and some of the objective factors (income and enterprise size). Hypothesis 3 , which assumed that a positive assessment of the subjective and objective factors has positive effects on the desire for continued employment, can also not be rejected. Yet here, too, the direct and indirect influence of the objective and subjective factors on the desire for continued employment is gender-specific. While four objective factors have a direct significant influence on the desire for continued employment among men, only one objective factor can contribute to explaining this desire among women.

The desire for continued employment among the male participants was influenced by their working hours (full-time employees are more likely to desire continued employment), their vocational position (white-collar workers are more likely to desire continued employment), their household income, the size of the enterprise and their recognition on the job (each with a negative correlation). On the subjective side, the desire for continued employment among male subjects can be explained by work motivation and organisational bonds (positive correlations in both cases). The perceived meaningfulness of the work, vocational status, and management/ 
leadership have additional indirect effects on the desire for continued employment through motivation.

The deviance in the desire for continued employment of female survey participants can be explained by their work ability, their vocational status, and their organisational bonds (each with a positive correlation). The perceived meaningfulness of the work, the demands and recognition on the job, income, and enterprise size have only indirect effect through their influence on work ability.

We can state that organisational bonds are a significant explanatory factor both for women and for men and therefore assume that employees who have worked in one enterprise for many years also have a distinct desire for continued employment.

Notably, meaningful work has a positive effect on the motivation of men and work ability on the motivation of women. Since precisely these two parameters strongly influence the respective desire for continued employment it is important that senior managers in enterprises be able to convince their employees of the meaningfulness of their work and the enterprise objective respectively. These results therefore suggest that employees should be informed of the objectives or of their contribution to achieving the objectives so that they are able to place their own work in a meaningful context. One possibility for this is increased participation in the development of objectives or partial objectives for the enterprise. Methods can be employed for this participative approach such as conducting strategy workshops, increasing teamwork, or mentors or sponsorships. It appears essential that female employees possess relevant work ability. In order to maintain the security of employability regular job-related skills enhancement measures could contribute to increasing the desire for continued employment.

There is already a great deal of evidence on devising age-appropriate work conditions. Many of these aspects can also be considered as implications for the desire for continued employment from this study. In particular, measures in the areas of management, task design, skills enhancement, and company culture appear to be wise approaches both to create a positive work atmosphere (before reaching retirement age), and ensure appreciation at all age levels. In general, age discrimination should be excluded as much as possible and a culture of knowledge sharing and experience transfer created. This can be achieved by means of deliberate team formation (collaboration among different age groups), through skills enhancement measures that are not offered on the basis of age, and through the opportunity to work independently (with regard to time and content). This course of action should apply as well for employment beyond retirement. These measures are nothing new, but the results of this study substantiate their relevance (Bundesministerium für Arbeit und Soziales 2010). Equal treatment of older employees could result in greater willingness to continue working.

In the context of this research, the availability of longitudinal data would be desirable since this is the only way to examine intention and realisation with regard to continued employment. In addition, persistent changes in motivation could be recorded, in particular in the event of drastic occurrences such as unemployment. It would also be advisable for future studies to survey not only directly affected older 
workers, but also a comparison group of younger employees in order to better differentiate period and cohort effects and be able to make assertions regarding future behaviours.

\section{References}

Agresti, Alan 2010: Analysis of Ordinal Categorical Data. $2^{\text {nd }}$ edition. Hoboken/New Jersey: John Wiley \& Sons.

Aittomäki, Akseli; Lahelma, Eero; Roos, Eva 2003: Work conditions and socioeconomic inequalities in work ability. In: Scandinavian Journal of Work, Environment and Health 29,2: 159-165.

Alavinia, Seyed Mohammad; van Duivenhooden, Cor; Burdorf, Alex 2007: Influence of work-related factors and individual characteristics on work ability among Dutch construction workers. In: Scandinavian Journal of Work, Environment and Health 33,5: 351-357.

Aschenbaum, Andrew W. 2005: Aging and changing: International Historical Perspectives on Aging. In: Johnson, Malcolm L. (Eds.): The Cambridge Handbook of Age and Ageing. Cambridge, UK: Cambridge University Press: 21-30.

Atchley, Robert 1989: A continuity theory of normal aging. In: The Gerontologist 29,2: 183-190 [doi:10.1093/geront/29.2.183].

Bäcker, Gerhard et al. 2009: Ältere Arbeitnehmer. Erwerbstätigkeit und soziale Sicherheit im Alter. Wiesbaden: VS Verlag für Sozialwissenschaften.

Beehr, Terry 1986: The Process of Retirement. A review and Recommendation for Future Investigation. In: Personnel Psychology 39,1: 31-55 [doi: 10.1111/j.1744-6570.1986. tb00573.x].

Beehr, Terry; Glazer, Sharon; Nielson, Norma L;. Farmer, Suzanne J. 2000: Work and Nonwork Predictors of Employees' Retirement Ages, Central Michigan University. In: Journal of Vocational Behaviour 57: 206-225 [doi:10.1006/jvbe.1999.1736].

berufsstart.de (Eds.) 2006: Kurzumfrage Attraktive Arbeitgeber 2006. URL: http://www. berufsstart.de/studien/attraktive_arbeitgeber/2006/index1.html, 13.08.2010.

Börsch-Supan, Axe/ 2011: Ökonomische Auswirkungen des demografischen Wandels. In: Politik und Zeitgeschichte (APuZ) 10-11: 19-26

Brussig, Martin; Wojtkowski, Sascha 2006: Durchschnittliches Rentenalter steigt weiter: wachsende Differenzierung im Rentenzugangsalter seit 2003 zu beobachten. Der Altersübergangs-Report. URL: http://www.iaq.uni-due.de/auem-report/2006/2006-02/ auem2006-02.pdf, 12.08.2010.

Büsch, Victoria; Dahl, Svenn-Aage; Dittrich, Dennis A.V. 2009: An empirical study of age discrimination in Norway and Germany. In: Applied Economics 41,5: 633-651.

Büsch, Victoria; Dorbritz, Jürgen; Heien, Thorsten; Micheel, Frank 2010: Weiterbeschäftigung im Rentenalter Wünsche - Bedingungen - Möglichkeiten. Heft 129: Materialien zur Bevölkerungswissenschaft des Bundesinstituts für Bevölkerungsforschung. URL: http://www.bib-demografie.de/cln_090/nn_750526/SharedDocs/Publikationen/DE/ Download/Materialienbaende/129, templateld $\bar{d}=$ raw, property=publicationFile.pdf/129. pdf

Bundesagentur für Arbeit (Eds.) 2011: Gleitender Übergang in den Ruhestand. http:// www.arbeitsagentur.de/zentraler-Content/Veroeffentlichungen/Merkblatt-Sammlung/MB14-GIUebergang-Ruhestand.pdf, 17.01.2012. 
Bundesministerium für Arbeit und Soziales (Eds.) 2010: Aufbruch in die altersgerechte Arbeitswelt, Bericht der Bundesregierung gemäß §154 Abs. 4, Sechstes Sozialgesetzbuch zur Anhebung der Regelaltersgrenze auf 67 Jahre. URL: http://www.healthatwork-online.de/fileadmin/downloads/altersgerechte_arbeitswelt.pdf, 17.01.2012.

Carter, Mary A. T.; Cook, Kelli 1995: Adaptation to retirement: Role changes and psychological resources. In: The Career Development Quarterly 44,1: 1995: 67-82.

Commerzbank AG (Eds.) 2009: Abschied vom Jugendwahn? In: Unternehmer Perspektiven, Unternehmerische Strategien für den demografischen Wandel.

Cronbach, Lee 1951: Coefficient alpha and the internal structure of tests. In: Psychometrika 16,3: 297-334 [doi: 10.1007/BF02310555].

Deller, Jürgen; Huch, Daniela; Kern, Stefanie; Maxin, Leena 2007: An empirical study of post-retirement activities: Economic and voluntary work of retired staff. Research Report. In: The Silver Workers Institute. International Association for the Studies of Insurance Economics (Eds.): Études et Dossiers No. 330. URL: http://www.genevaassociation.org/PDF/Working paper series/GA\%20E\&D\%20330\%20-\%20Silver\%20 Workers-Research\%20Report.pdf, 17.06.2011.

Deller, Jürgen; Maxin, Leena 2010: Silver Work: Zum Stand beruflicher Aktivitäten im Ruhestand in Deutschland. In: Informationsdienst Altersfragen 37,2: 3-8. URL: http://www.dza.de/fileadmin/dza/pdf/Heft_02_2010_Maerz_April_2010_gesamt.pdf, 02.12.2010.

Dorbritz, Jürgen; Micheel, Frank 2010: Weiterbeschäftigung im Rentenalter: Potenziale, Einstellungen und Bedingungen. In: Bevölkerungsforschung Aktuell 3/2010: 2-7. URL: http://www.bib-demografie.de/cln_099/nn_1890424/SharedDocs/Publikationen/DE/ Download/Bevoelkerungsforschung Aktuell/bev aktuell 0310,templateld $=\mathrm{raw}, \mathrm{p}$ roperty=publicationFile.pdf/bev_aktuell_0310.pdf, 02.12.2010.

Eurostat (Eds.) 2010: Europe in figures. Eurostat yearbook 2010. Luxembourg. URL: http://epp.eurostat.ec.europa.eu/cache/ITY_OFFPUB/KS-CD-10-220/EN/KS-CD-10220-EN.PDF 01.07.2011.

Feldman, Danie/ C. 1994: The Decision to Retire Early: A review and Conceptualisation. In: The Academy of Management Review 19,2: 285-311 [DOI:10.2307/258706].

Gärtner, Karla 2010: Zusammenhänge zwischen subjektiver Gesundheit und der Bereitschaft zur Weiterbeschäftigung. In: Bevölkerungsforschung Aktuell 03/2010: 7-10 http://www.bib-demografie.de/nn_750528/SharedDocs/Publikationen/DE/Download/ Bevoelkerungsforschung Aktueli/bev aktuell 0310, templateld $=$ raw, property $=p$ ublicationFile.pdf/bev_aktuell_0310.pdf, 17.01.2012.

Gobeski, Kirsten; Beehr, Terry 2009: How retirees work: predictors of different types of bridge employment. In: Journal of Organizational Behavior 30,3: 401-425 [doi: 10.1002/job.547].

Goodman, Leo A: Kruskal, William H. 1954: Measures of association for cross classifications. In: Journal of the American Statistical Association 49: 732-764.

Grube, Anna; Hertel, Guido 2008: Altersbedingte Unterschiede in Arbeitsmotivation, Arbeitszufriedenheit und emotionalem Erleben während der Arbeit. In: Wirtschaftspsychologie 10,3: 18-29.

Hauser, Frank; Schubert, Andreas; Aicher, Mona 2005: Unternehmenskultur, Arbeitsqualität und Mitarbeiterengagement in den Unternehmen in Deutschland. Ein Forschungsprojekt des Bundesministeriums für Arbeit und Soziales. Abschlussbericht Forschungsprojekt 18/05. In: bmas.de 12.08.2010. URL: http://www.bmas. de/SharedDocs/Downloads/DE/PDF-Publikationen/forschungsbericht-f371.pdf? blob=publicationFile, 17.01..2012 
Henkens, Kène 2005: Stereotyping Older Workers and Retirement: The Managers' Point of View. In: Canadian Journal on Aging 24,4: 353-366 [doi: 10.1353/cja.2006.0011].

Hershey, Douglas A.; Jacobs-Lawson, Joy M.; Neukam, Kristan A. 2002: Influences of Age and Gender on Workers' Goals for Retirement. In: International Journal of Aging and Human Development 55,2: 163-179.

Herzberg, Frederick; Mausner, Bernhard; Bloch Snyderman, Barbara 2010: The motivation to work. $12^{\text {th }}$ edition New Brunswick [u.a.]: Transaction Publisher.

Humphrey, Alan et al. 2003: Factors Affecting the Labour Market Participation of Older Workers. URL: http://193.129.121.133/asd/asd5/rports2003-2004/rrep200.pdf, 14.08.2010.

IImarinen, Juhani; Tuomi, Kaija; Klockars, Matti 1997: Changes in the Work Ability of Active Employees over an 11-year period. In: Scandinavian Journal of Work, Environment and Health 1997;23 suppl 1: 49-57.

IImarinen, Juhani; Tuomi; Kaija 2004: Present and Future of Work Ability. In: IImarinen, Juhani 2005: Towards a longer worklife. Helsinki: Finnish Institute of Occupational Health and the Ministery of Social Affairs and Health.

ILO Global Report 2011: Equality at work: The continuing challenge. Global Report under the follow-up to the ILO Declaration on Fundamental Principles and Rights at Work. International Labour Conference: 100th Session 2011. International Labour Office: Geneva.

Kapteyn, Arie; Smith, James P.; van Soest, Arthur; Banks. James 2007: Labor Market Status and Transitions during the Pre-Retirement Years - Learning from International Differences, WR 536. URL: http://www.rand.org/content/dam/rand/pubs/working_papers/2007/RAND_WR536.pdf, 16.01.2012.

Kanfer, Ruth; Ackermann, Phillip L. 2004: Aging, Adult Development, and Work Motivation. In: Academy of Management Review 29,3: 440-458.

Klehe, Ute-Christine; Kleinmann, Martin 2007: Typische versus maximale Arbeitsleistung. In: Schuler, Heinz; Sonntag, Karlheinz (Eds.): Handbuch der Arbeits- und Organisationspsychologie Vol. 6. Göttingen: Hogrefe Verlag: 254-260.

Koloski, Karl; Ekerdt, David; DeViney, Stanley 2001: The Role of Job-Related Rewards in Retirement Planning. In: The Journals of Gerontology, Series B: Psychological Sciences and Social Sciences 56,3: 160-169 [doi: 10.1093/geronb/56.3.P160].

Kooij, Dorien; Jansen, Paul G. W.; Dikkers, Josje S. E.; De Lange, Annet H. 2010: The influence of age on the associations between HR practices and both affective commitment and job satisfaction: A meta-analysis. In: Journal of Organizational Behavior 31,8: 1111-1136 [doi: 10.1002/job.666].

Kruse, Andreas 2000: Psychologische Beiträge zur Leistungsfähigkeit im mittleren und höheren Erwachsenenalter: eine ressourcenorientierte Perspektive. In: von Rothkirch, Christoph (Eds.): Altern und Arbeit: Herausforderung für Wirtschaft und Gesellschaft: Beiträge, Diskussionen und Ergebnisse eines Kongresses mit internationaler Beteiligung. Berlin: Edition Sigma: 72-87.

Küppers, Wendelin; Wunderer, Rolf 2001: Leistungsmanagement neu fokussieren: Motivationsbarrieren erkennen und reduzieren. Ergebnisse einer empirischen Untersuchung. In: Personalwirtschaft 8: 28-31.

Küppers, Wendelin; Wunderer, Rolf 2003: Motivationsbarrieren im Unternehmen. In: Personalmagazin 2: 58-61.

Laschart, Maragarete; Möller, Heidi 2005: Der ältere Arbeitnehmer - ein vernachlässigtes Subjekt in der Personalentwicklung. In: Journal for Psychology 13,1/2: 127-146. 
Lehr, Ursula 1990: Ältere Arbeitnehmer heute und morgen: Berufliche Leistungsfähigkeit und Übergang in den Ruhestand. In: Späth, Lothar; Lehr, Ursula (Eds.): Altern als Chance und Herausforderung. Vol. 1: Aktives Altern. Stuttgart: Verlag Bonn aktuell: 97-124.

Lieberman, Morton A.; Tobin, Sheldon S. 1983: The experience of old age: Stress, coping, and survival. New York: Basic Books.

Lord, Robert 2002: Traditional Motivation Theories and older Engineers, In: Engineering Management Journal 14,3: 3-7.

Lord, Robert; Farrington, Phillip 2006: Age-related differences in the motivation of knowledge workers. In: Engineering Management Journal 18,3: 20-26.

Maslow, Abraham H. 2010: Motivation und Persönlichkeit, $12^{\text {th }}$ edition. Reinbek bei Hamburg, Rowohlt.

Micheel, Frank; Roloff, Juliane; Wickenheiser, Ines 2011: Die Bereitschaft zur Weiterbeschäftigung im Ruhestandsalter im Zusammenhang mit sozioökonomischen Merkmalen. In: Comparative Population Studies - Zeitschrift für Bevölkerungswissenschaft 35,3: 833-868 [doi: 10.4232/10.CPoS-2010-19de]

Mollenhauer, Rudi 2006: Rente mit 67 - Pro und Kontra. In: Deutscher Bundestag (Eds.): Der aktuelle Begriff 25/06, 07.06.2006: 15-18. URL: http://www.bundestag.de/wissen/ analysen/2006/Der_aktuelle_Begriff_2006.pdf, 12.08.2010.

Mutran, Elizabeth; Reitzes, Donald C.; Fernandez, Maria E. 1997: Factors that influence Attitudes Toward Retirement. In: Research on Aging 19,3: 251-273 [doi: 10.1177/0164027597193001].

Opaschowski, Horst W. 2008: Deutschland 2030: Wie wir in Zukunft leben. $2^{\text {nd }}$ edition. Gütersloh: Gütersloher Verlagshaus.

Phillipson, Chris; Smith, Allison 2005: Extending working life - A review of the research literature. Research Report No 299. URL: http://research.dwp.gov.uk/asd/asd5/ rports2005-2006/rrep299.pdf, 16.01.2012.

Quick, Heather E.; Moen, Phyllis 1998: Gender, employment and retirement quality: A life course approach to the differential experiences of men and women. In: Journal of Occupational Health Psychology 3,1: 44-64 [doi:10.1037/1076-8998.3.1.44].

Rabl, Tanja 2010: Age, discrimination, and achievement motives - A study of German Employees. In: Personnel Review 39,4: 448-467 [doi: 10.1108/00483481011045416].

Rhodes, Susan R. 1983: Age-Related Differences in Work Attitudes and Behavior: A Review and Conceptual Analysis. In: Psychological Bulletin 93,2: 328-367.

Rump, Jutta; Eilers, Silke 2009: Ökonomische Effekte des Age Managements. Sternenfels: Verlag Wissenschaft und Praxis.

Sebald, Harriet; Kramarsch, Michael E. 2007: Was Mitarbeiter bewegt zum Unternehmenserfolg beizutragen: Mythos und Realität. In: Towers, Perrin (Eds.): Global Workforce Study 2007-2008. URL: http://www.towersperrin.com/tp/ getwebcachedoc?webc $=$ HRS/DEU/2008/200801/TPGWSGermany.pdf, 12.08.2010.

Shacklock, Kate; Brunetto, Yvonne; Nelson, Silvia 2009: The Different Variables that Affect Older Males' and Females' Intentions to Continue Working. In: Asia Pacific Journal of Human Resources 47,1: 79-101 [doi: 10.1177/1038411108099291].

Shultz, Kenneth S. 2003: Bridge employment: Work after retirement. In: Adams, Gary A.; Beehr, Terry A. (Eds.): Retirement: Reasons, processes, and results. New York: Springer. 215-241. 
Siegrist, Johannes et al. 2004: The measurement of Effort-Reward Imbalance at work: European comparisons. In: Social Science \& Medicine 58,8: 1483-1499 [doi:10.1016/ S0277-9536(03)00351-4].

Skirbekk, Vegard 2003: Age and Individual Productivity. MPIDR Working Paper WP 2003-028. URL: http://www.demogr.mpg.de/papers/working/wp-2003-028.pdf, 23.08.2011.

Smeaton, Deborah; McKay, Stephen 2003: Working after State Pension Age: Quantitative Analysis. London: Department for Work and Pensions, Research Report 182. URL: http://research.dwp.gov.uk/asd/asd5/rrep182.pdf, 12.08.2010.

Stamov Roßnagel, Christian 2009: Die Arbeitsmotivation älterer Beschäftigter: Aktive Regulation statt passiven Abbaus. In: Kocka, Jürgen; Kohli, Martin; Streeck, Wolfgang (Eds.): Altern in Deutschland: Familie, Zivilgesellschaft, Politik. Nova Acta Leopoldina N.F. 106 No. 370. Stuttgart: 59-75, wissenschaftliche Verlagsgesellschaft mb.

Tuomi, Kaija; Huuhtanen, Pekka; Nykyri, Erkki; IImarinen Juhani 2001: Promotion of Work Ability, the Quality of Work and Retirement. In: Occupational Medicine 51,5: 318-324 [doi: 10.1093/occmed/51.5.318].

van Dam, Karen; van der Vorst, Janine; van der Heijden, Beatrice 2009: Employees' Intentions to Retire Early: A Case of Planned Behavior and Anticipated Work Conditions. In: Journal of Career Development 35,3: 265-289 [doi: 10.1177/0894845308327274].

von Bonsdorff, Monika E.; Shultz, Kenneth S.; Leskinen, Esko; Tansky, Judith 2009: The choice between retirement and bridge employment: A continuity and life course perspective. In: International Journal of Aging and Human Development 69,2: 79-100 [doi:10.2190/AG.69.2.a].

Wang, Mo; Zhan, Yujie; Liu, Songqi; Shultz, Kenneth S. 2008: Antecedents of bridge employment. A longitudinal Investigation. In: Journal of Applied Psychology 93,4: 818-830 [doi: 10.1037/0021-9010.93.4.818].

Wang, Mo; Shultz, Kenneth 2010: Employee Retirement: A Review and Recommendations for Future Investigations. In: Journal of Management 36,1: 172-206 [doi: 10.1177/0149206309347957].

Warr, Peter 1994: Age and Employment. In: Triandis, Harry C. (Eds.): Handbook of Industrial and Organizational Psychology Vol. 4. Palo Alto: Consulting Psychologists Press: 485-550.

Warr, Peter 2001: Age and work behaviour: Physical attributes, cognitive abilities, knowledge, personality traits and motives. In: International Review of Industrial and Organizational Psychology 16: 1-36.

Zacher, Hannes; Degner, Manuela; Seevaldt, Robert; Frese, Michael 2009: Was wollen jüngere und ältere Erwerbstätige erreichen? Altersbezogene Unterschiede in den Inhalten und Merkmalen beruflicher Ziele. In: Zeitschrift für Personalpsychologie 8,4: 191-200 [doi: 10.1026/1617-6391.8.4.191]. 
Translated from the original text by the Federal Institute for Population Research, for information only. The reviewed and author's authorised original article in German is available under the title Determinanten der Arbeitsmotivation und Leistungsfähigkeit älterer Arbeitnehmer und Auswirkungen auf den Weiterbeschäftigungswunsch", DOI 10.4232/10.CPoS-2010-20de or URN urn:nbn:de:bib-cpos-2010-20de9, at http://www.comparativepopulationstudies.de.

Date of submission: 31.08 .2010

Date of Acceptance: 02.02.2012

Prof. Dr. Victoria Büsch ( $₫)$. SRH Hochschule Berlin, 10587 Berlin, Germany. E-Mail: victoria.buesch@srh-hochschule-berlin.de

Prof. Dr. Dennis A. V. Dittrich. Jacobs University Bremen, Jacobs University's School of Humanities and Social Sciences, 28759 Bremen, Germany.

E-Mail: d.dittrich@jacobs-university.de

Prof. Dr. Uta Lieberum. Hochschule Fresenius, Standort Hamburg, 20148 Hamburg, Germany. E-Mail: lieberum@hs-fresenius.de 


\section{Comparative Population Studies - Zeitschrift für Bevölkerungswissenschaft}

wWw.comparativepopulationstudies.de

ISSN: 1869-8980 (Print) - 1869-8999 (Internet)

Published by / Herausgegeben von

Prof. Dr. Norbert F. Schneider

Layout and print: Federal Institute for Population Research, Wiesbaden (Germany)

Managing Editor / Redaktion

Frank Swiaczny

\section{Copy Editor / Schlussredaktion}

Dr. Evelyn Grünheid

\section{Scientific Advisory Board / Wissenschaftlicher Beirat}

Jürgen Dorbritz (Wiesbaden)

Paul Gans (Mannheim)

Johannes Huinink (Bremen)

Marc Luy (Wien)

Clara H. Mulder (Groningen)

Notburga Ott (Bochum)

Peter Preisendörfer (Mainz)

\section{Board of Reviewers / Gutachterbeirat}

Martin Abraham (Erlangen)

Laura Bernardi (Lausanne)

Hansjörg Bucher (Bonn)

Claudia Diehl (Göttingen)

Andreas Diekmann (Zürich)

Gabriele Doblhammer-Reiter (Rostock)

Henriette Engelhardt-Wölfler (Bamberg)

E.-Jürgen Flöthmann (Bielefeld)

Alexia Fürnkranz-Prskawetz (Wien)

Beat Fux (Zürich)

Joshua Goldstein (Rostock)

Karsten Hank (Köln)

Sonja Haug (Regensburg)

Franz-Josef Kemper (Berlin)

Michaela Kreyenfeld (Rostock)

Aart C. Liefbroer (Den Haag)

Kurt Lüscher (Konstanz)

Dimiter Philipov (Wien)

Tomáš Sobotka (Wien)

Heike Trappe (Rostock) 